\title{
Bifidez pieloureteral proximal derecha incompleta y triplicidad pieloureteral proximal izquierda incompleta
}

\author{
Monllau Font V, Segarra Tomás J, Alberola J, Pascual M, Sánchez Martín FM, \\ Millán Podríguez F, Villavicencio Mavrich H.
}

Servicio de Urología. Fundació Puigvert. Barcelona

Actas Urol Esp. 2008;32(10):1046

Mujer de 75 años, con antecedentes de HTA, histerectomía, mastectomía derecha por neoplasia de mama y gastrectomía parcial por perforación, que ingresa en otro centro para estudio de síndrome febril de origen desconocido. La paciente niega antecedentes urológicos.

Remitida a Nuestro Centro para estudio de dudosa litiasis en uréter distal izquierdo, visualizada por TC. Se solicitan:

- Ecografía Reno-Vesical: mínima ectasia pielocalicilial en riñón izquierdo, con dilatación ureteral izquierda, sin poder determinar la causa.

- U.I.V: ausencia de imágenes radioopacas en la Rx simple. Funcionalismo renal bilateral conservado.
Se observa bifidez pieloureteral proximal derecha incompleta y, en sistema colector izquierdo, triplicidad pieloureteral proximal incompleta, con uréter distal común de mayor calibre, sin signos de uropatía obstructiva. Se visualizan también, imágenes saculares vesicales compatibles con divertículos de Hutch.

\footnotetext{
Correspondencia autor: Dra. V. Monllau Font Servicio de Urología. Fundació Puigvert Cartagena, 340-350 - 08025 Barcelona Tel.: 934169700 E-mail autor: 37359vmf@comb.es Información artículo: Imágenes en Urología Trabajo recibido: junio 2007 Trabajo aceptado: julio 2007
}

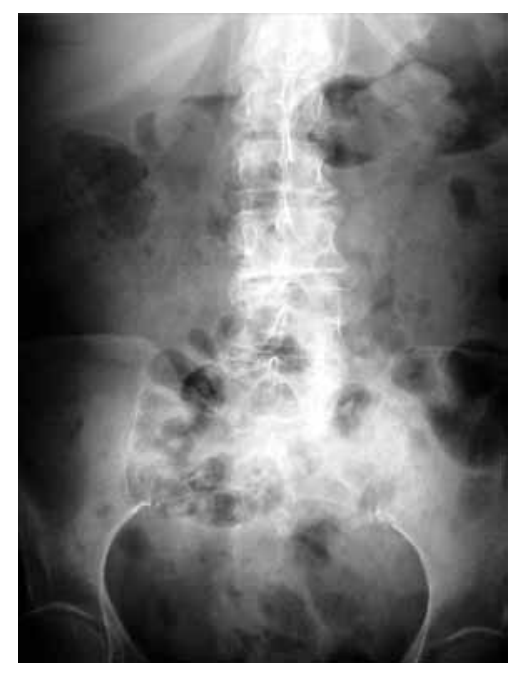

FIGURA 1

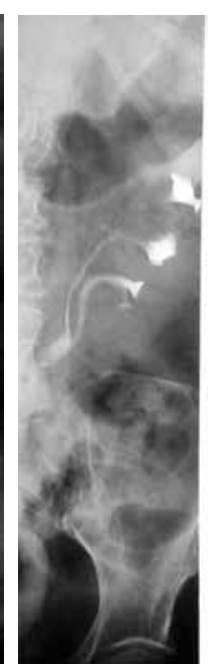

FIGURA 2
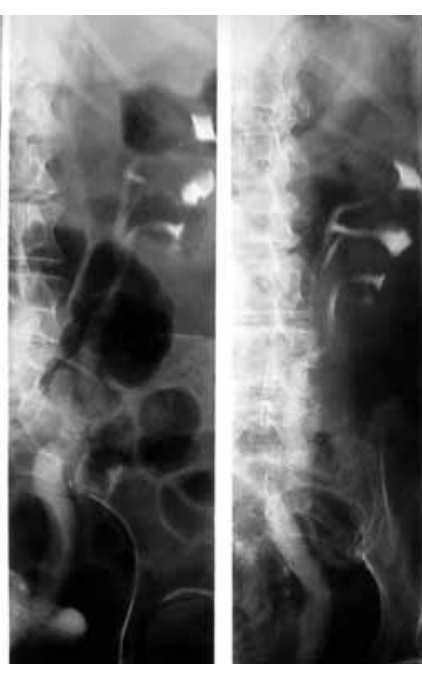

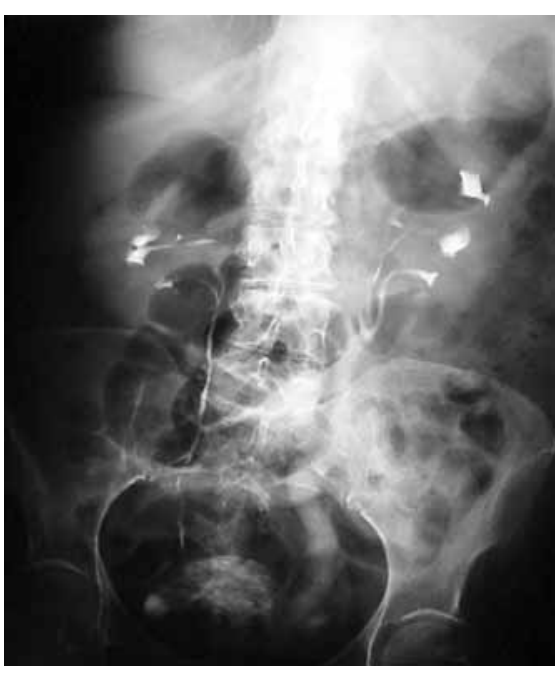

FIGURA 3 